\title{
The relationship between remuneration and financial performance for companies listed on the Johannesburg Stock Exchange
}

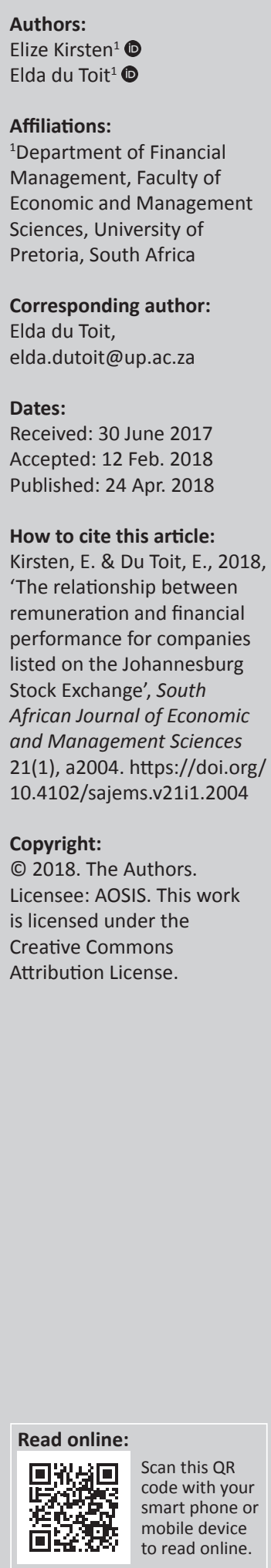

Background: The executive directors of a company are the agents of the shareholders and should manage the company in the best interest of the shareholders, not only for personal gain. It is therefore important for companies to ensure that they implement remuneration policies which will result in motivated employees who will execute decisions and actions which are in the best interest of the shareholders. However, it is widely acknowledged that the relationship between company performance and executive remuneration is weak. This implies that executives are still rewarded excessive remuneration regardless of the performance of their companies.

Aim: The purpose of this study was to determine whether a relationship exists between the performance-based remuneration of executive directors and the financial performance of South African companies.

Setting: The study was conducted in South Africa, specifically on companies listed on the Johannesburg Stock Exchange.

Methods: The study design was quantitative and made use of a Pearson correlation and generalised least squares regression with bootstrapping at a $95 \%$ confidence interval to analyse the relationship between executive director remuneration and the financial performance of 42 companies in the consumer goods and services industry of the Johannesburg Stock Exchange (JSE) from 2006 to 2015.

Results: The study established that the remuneration policies in place for South African executive directors within the consumer goods and services industry seem to be affected by the share price of the company.

Conclusion: In the South African environment, executive director remuneration is thus not directly related to profitability or company size, as was the case in some earlier studies. The link between executive director remuneration and share performance may be an indication that remuneration policies are based on the share price and are thus directly connected to the principle of shareholder wealth maximisation.

\section{Introduction}

Companies that give their executives the right rewards should outperform their peers under the right circumstances (Wilkinson 2009). However, it has been argued that short-termism in remuneration packages to executives, even if performance-related, were in part responsible for the global economic crisis, which was a result of the collapse in the market capitalisation of banks in the United States (Bebchuk \& Spamann 2010; Fahlenbrach \& Stulz 2011; Rajan 2005). Employees who are strongly motivated by money and personal gain may also be tempted to commit fraud (see for example Gill, Prowse and Vlassopoulos (2012) and Brick, Palmon and Wald (2006)).

Colvin (2008) emphasises that any form of compensation should relate to the performance of a company, because many chief executive officers (CEOs) are receiving excessive amounts of remuneration, often in the form of share options, despite their companies' financial problems. Xiaoning (2009) reported that Chinese investors were up in arms after they had received reports showing that senior executives of loss-making companies rewarded themselves with immense general compensation packages. De Wet (2013) found that similar objections against excessive executive remuneration had been heard from across the globe. The situation in South Africa is unfortunately no exception. 
One may argue that high overall compensation is appropriate for the management of larger firms. As these firms are generally more complex and demanding to operate, a specific skill set is needed, which requires comparable compensation (Coughlan \& Schmidt 1985; Sigler 2011). Performance-based remuneration is a common incentive system used by companies to motivate employees and to improve productivity and performance. Schulz (1997) and Kuo, Ting and Chiu (2013) discovered that firms with profit sharing and employee share ownership plans experienced increased employee productivity and performance. Jensen and Murphy (2010), Murphy (1985) and Sun, Zhao and Yang (2010) found that remuneration of executives is to some extent related to the observed productivity of a company. Studies with similar results have been conducted around the world by authors such as McGee et al. (2006), Lourenco (2010) and Pascual-Ezama, Prelec and Dunfield (2013). However, other studies such as those by Gill et al. (2012), Samnani and Singh (2014) and Aguinis, Joo and Gottfredson (2013) indicated that rewarding employees based on performance leads to decreased motivation and increased fraud, employee bullying and other types of unsavoury behaviour in the workplace. Even though the economic theories of efficient compensation forecast a positive relationship between company performance and executive remuneration, the efforts of researchers to document this relationship have been mostly unsuccessful. O'Neill and Iob (1999) and Ozkan (2007) found little evidence to suggest any consistent relationship between executive remuneration and measures of performance. This may imply that executives are still rewarded with remuneration packages out of proportion to their efforts and the performance of their companies.

De Wet (2013) conducted a study on executive director remuneration in South Africa, using economic value added (EVA) and market value added (MVA) as proxies for performance. This is a unique approach, as most previous studies observed measures for size (in terms of turnover or net assets) and measures for profitability. More recent studies include those by Bussin (2015), Bussin and Blair (2015), Bussin and Modau (2015) and Bussin and Nel (2015). It is necessary to compare the results of our study with those of the majority of studies available. The main purpose of this study is thus to investigate the relationship between total executive director remuneration packages and the financial performance of South African companies listed on the Johannesburg Stock Exchange (JSE).

The results provide some interesting insights, such as that executive director remuneration is mainly related to the value of the company, rather than financial performance as shown in the financial statements. These findings are significant to shareholders, as they provide evidence that executive directors are compensated for increasing company value, which benefits shareholders directly. From a practical perspective, the findings of this study should aid managers and decision makers of South African companies in designing and implementing suitable reward systems to motivate employees and improve productivity. The findings would also provide investors with an additional proxy in the form of executive director remuneration to evaluate a company's potential performance.

The study is presented as follows. The literature review, in which previous research on the topic is investigated, is followed by a description of the research design and methods used in this study. A discussion of the results of the study follows. Conclusions in terms of the research and recommendations for further research are presented in the final section.

\section{Literature review}

\section{The agency problem and performance-based remuneration}

The theoretical foundation of this paper lies in agency theory. Multiple factors influence the relationship between performance-based remuneration and the overall performance of a company. The agency relationship is deemed the most important and influential of these factors. An agency relationship is defined as a contractual agreement under which one or more parties, known as the principals, engage another party or parties, known as the agents, to perform a specific service on their behalf (Boshkoska 2015; De Wet 2013; Jensen \& Meckling 1976; Kuo et al. 2013). Managers, as the agents of a company, would not act on behalf of the company if their interests are not fully aligned with those of the company (Dyl 1988). Jensen and Meckling (1976) claimed that managers are unlikely to maximise the wealth of a firm, even if the manager is the only shareholder. Bryant and Davis (2012), however, argue that the agency problem can be controlled by incentivising managers, as agents, to act in line with the interests of the company. There are various methods by which a company's shareholders can control the operations of the managers. One of these methods is the use of performance-based remuneration (Boshkoska 2015). Companies thus incur agency costs in the form of, for example, incentive schemes to motivate managers to run the company in the best interest of the shareholders and to maximise shareholder wealth in a sustainable manner (Coughlan \& Schmidt 1985; De Wet 2013). Remuneration policies should aim towards long-term value creation in a company (IoDSA 2016).

A variety of studies focus on executive compensation and how this can minimise the agency problem (Bebchuk \& Fried 2003). Reward systems are designed to bridge the agency problem between shareholders and managers, but to bridge this gap, reward systems must be related to the performance of managers and the strategy of the company, and take into account the growth and nature of the company. Reward systems should not only motivate employees, but also enhance the overall corporate values of the company (Kuo et al. 2013). Gill et al. (2012) and Shin (2013) suggest that companies with bonus-based pay structures should consider that worker dishonesty might be an unintended consequence. 
Studies such as those by Edmans and Gabaix (2009), Tosi and Gomez-Mejia (1994) and Yanadori and Milkovich (2002) narrowed the focus from executive compensation to that of the CEO of a company. The role of the CEO is pivotal in managing the resources of a company, especially in the context of a continuously changing external economic environment, to ensure value creation for shareholders. There is increased scrutiny levelled at the remuneration committees of companies, especially those that have increased CEO compensation, even when they face disappointing financial results (Bussin 2015). Gomez-Mejia, Tosi and Hinkin (1987) used CEO remuneration as a proxy for executive compensation and concluded that the payment of CEOs is more responsive to performance in companies that have dominant shareholders and are owner controlled. The allocation of company profits is generally based on the condition of achieving a certain level of return on equity employed or a specified dividend, or even both. The aim of a bonus fund is primarily to regulate the use of company funds, as well as safeguard the shareholders' interests (Merrett \& White 1968).

The main determinant for executive remuneration is often firm size, based on the revenue figure of the company (Baumol 1959; Conyon 1997; Jensen \& Murphy 2010; Murphy 1985). Executives may thus pursue a goal of sales maximisation, rather than wealth maximisation. Coughlan and Schmidt (1985) opine that the practice to base the bonuses of CEOs on sales growth is not always the most optimal compensation policy. In a case were an executive is near retirement and expects a bonus-based on sales or sales growth, this executive might approve excessive expenditures for advertising campaigns or other increases in the sales force to ensure increased sales revenues, even though this might exceed the profit-maximising levels.

A study by Anderson and Bizjak (2003) found that CEOs who are members of their own compensation committees receive less overall compensation and have a large ownership share. According to the study, these compensation committees were doing more to link executive pay to the performance of the company than those of the control sample. To support this, Sigler (2011) found that independent executive directors, and the consultants hired to advise the board, have relatively little motivation to safeguard the interests of the company's shareholders.

Another method to link executive compensation to the overall performance of the company is using long-term incentive plans (LTIPs). Pass (2003) found that most LTIPs were undemanding and rewarded average instead of outstanding performance. Buck et al. (2003) concluded that LTIPs are generally associated with reductions in the sensitivity of the relationship between executives' total rewards and shareholder returns and thus questioned their effectiveness. Walker (2010) also concluded that there is an inadequate relationship between executive compensation and long-term company performance.
Various arguments state that executive remuneration policies played a role in the onset of the global economic crisis. According to Bebchuk and Spamann (2010), Fahlenbrach and Stulz (2011) and Bussin (2015), the global economic crisis was a result of dramatic disintegration in the market capitalisation of USA banks. Rajan (2005) suggests that the significant risks experienced by the global financial sector was, in part, a result of the compensation practices used within this sector. He argued that, even though executives in the financial sector were engaging in business practices that were eroding performance and threatening sustainability of the companies and, by implication, the entire financial system, these executives were still receiving substantial incentive pay-outs. This argument was based on the outlook that a weak performance-pay relationship exists, which allows risky business practices.

A perfect compensation plan - one which links performance to payment - seems impossible to construct. However, Hovy (2005) concluded that the most feasible mechanism to align shareholder wealth creation with executive performance is global performance-based remuneration plans. To achieve this, companies can follow the guidelines provided by Van Zyl Smit and Nel (2010), who claim that remuneration policies should embrace three basic principles, namely appropriateness, fairness and effectiveness, and should be tightly aligned with the long-term value and soundness of the company.

According to Coughlan and Schmidt (1985) an optimal remuneration package should not be based solely on share options or other direct relationships between share performance and pay. A more efficient remuneration package is one which combines share-related components with components which are not linked to shareholder wealth, such as a salary or a bonus. At the discretion of the executive directors, a portion of the bonus can even be linked to share price performance as a signal that the share price is regularly being monitored (Coughlan \& Schmidt 1985). A mix of the various components of pay into a single compensation package for an executive director allows for the deficiencies of one component to be counterbalanced by another component's strength. Including a cash bonus in the package motivates executive directors to focus on the short-term goals of the company, which counters the limitations of restricted share, namely only rewarding achievement of long-term goals (Sigler 2011).

According to the economic theories of compensation, the performance of a company should only influence an executive director remuneration to the point where it serves as a substitute for unobservable managerial efforts and productivity. Even though most of the theories suggest a correlation between executive compensation and company performance, most of them do not mention the measure of performance. Since the shareholders of the company are the principles within the agency theory, it would seem appropriate to define and measure performance in terms of shareholder return instead of accounting profits (Murphy 1985). 
Measurement tools can be used to indicate whether the company achieved or surpassed their goals and objectives. Performance measures can also be used to evaluate, control and improve the production processes of the company (Ghalayini \& Noble 1996). Performance measurement is thus a process which quantifies the efficiency and effectiveness of actions. The action leads to performance, while the measurement is the quantification process. The level of performance a business attains, is a function of how efficient and effective it undertook all of its actions (Neely, Gregory \& Platts 2005). The two approaches most commonly used to empirically evaluate the financial performance of companies are accounting-based measures and market-based measures (Cochran \& Wood 1984; Spicer 1978). Market-based measures are those that use corporate share returns to indicate the performance of a company (Kuo et al. 2013), while accountingbased measures use performance measures from the financial statements, such as profit.

According to Bourne et al. (2000), performance management has a dual purpose. The first is the success of the chosen strategy's implementation as a result of the measures derived from the chosen strategy. The second is that the information and feedback received from the measures should be used to test the strategy's validity and challenge the assumptions made. The main purpose of performance management can thus be seen as an examination of past performance to stimulate future actions (Neely et al. 2005). It is important to note that, to gain the full potential of performance measures, consistency within the implementation of these measures is needed. As Mintzberg (1978) emphasised, strategies can be realised only through the consistency of actions.

\section{Relationship between company performance and executive director remuneration}

There are many empirical studies that focused on the relationship between company performance and executive director remuneration. However, many failed to produce conclusive results and consensus (Bruce, Buck \& Main 2005; Bussin \& Blair 2015). Some of these papers include those by Cosh (1975), Hirschey and Pappas (1981), Lewellen and Huntsman (1970), Masson (1971) and Meeks and Whittington (1975). All of these papers made use of accounting information to measure the profitability of companies. As a result, the authors encountered measurement errors which led to biased empirical results (Coughlan \& Schmidt 1985). Table 1 below provides a summary of some of the previous research that investigated the relationship between company performance

TABLE 1: Summary of previous research.

\begin{tabular}{|c|c|c|}
\hline Authors & Country & Finding \\
\hline Lewellen and Huntsman (1970) & United States & $\begin{array}{l}\text { Stronger relationship between executive compensation and profit than between executive } \\
\text { compensation and sales. }\end{array}$ \\
\hline Masson (1971) & United States & Executive compensation is related to stock market performance and not sales performance. \\
\hline Cosh (1975) & United Kingdom & $\begin{array}{l}\text { Company size is the major determinant of executive compensation, but for some industries } \\
\text { profitability was also significant. }\end{array}$ \\
\hline Meeks and Whittington (1975) & United Kingdom & $\begin{array}{l}\text { There is a positive relationship between executive compensation and sales, but no significant } \\
\text { relationship between executive compensation and profitability. }\end{array}$ \\
\hline Hirschey and Pappas (1981) & United States & $\begin{array}{l}\text { Small companies show a relationship between sales and executive compensation, while large } \\
\text { companies show a relationship between profit and executive compensation. }\end{array}$ \\
\hline Coughlan and Schmidt (1985) & United States & $\begin{array}{l}\text { Executive compensation is sometimes related to sales growth but shows a stronger relationship } \\
\text { to share price performance. }\end{array}$ \\
\hline Murphy (1985) & United States & $\begin{array}{l}\text { A strong link between company performance, in terms of shareholder returns and sales growth, } \\
\text { and executive director remuneration. }\end{array}$ \\
\hline Gomez-Mejia et al. (1987) & United States & Positive relationship between performance and executive compensation. \\
\hline Dyl (1988) & United States & $\begin{array}{l}\text { The level of executive director compensation is generally related to the number of shareholders } \\
\text { (extent to which a company is closely held). }\end{array}$ \\
\hline Conyon (1997) & United Kingdom & $\begin{array}{l}\text { The main force behind executive remuneration is firm size, often based on sales. There is a positive } \\
\text { relationship between executive compensation and current shareholder returns. }\end{array}$ \\
\hline Conyon, Peck and Sadler (2000) & United Kingdom & $\begin{array}{l}\text { Executive director remuneration is positively related to shareholders return but not necessarily to } \\
\text { earnings per share (EPS). }\end{array}$ \\
\hline Fatemi, Desai and Katz (2003) & United States & Strong relationship between executive director remuneration and MVA. \\
\hline Alshimmiri (2004) & United Arab Emirates & $\begin{array}{l}\text { A negative relationship between management remuneration and performance in terms of return } \\
\text { on equity (ROE) and return on assets (ROA). }\end{array}$ \\
\hline Bruce et al. (2005) & United Kingdom and Germany & $\begin{array}{l}\text { No conclusive results on the relationship between executive compensation and company } \\
\text { performance. }\end{array}$ \\
\hline Brick et al. (2006) & United States & $\begin{array}{l}\text { Found evidence which showed that excessive executive compensation is linked to firm under- } \\
\text { performance. }\end{array}$ \\
\hline Mueller (2006) & United States & Discovered that company size is the best predictor of management compensation. \\
\hline Haynes, Thompson and Wright (2007) & United Kingdom & Executive director remuneration is significantly influenced by the size of the company. \\
\hline Kato, Kim and Lee (2007) & Korea & Found a significant relationship between executive remuneration and stock market performance. \\
\hline Zhu (2007) & China & $\begin{array}{l}\text { Positive correlation between top management remuneration and return on equity (ROE), total } \\
\text { assets and the number of managers. }\end{array}$ \\
\hline Duffhues and Kabir (2008) & Netherlands & $\begin{array}{l}\text { No distinct relationship between executive director remuneration packages and company } \\
\text { performance. }\end{array}$ \\
\hline Frydman and Saks (2010) & United States & $\begin{array}{l}\text { The relationship between executive directors' pay and company size has grown since the 1970s } \\
\text { because of increased incentives. }\end{array}$ \\
\hline
\end{tabular}


TABLE 1 (Continues...): Summary of previous research.

\begin{tabular}{|c|c|c|}
\hline Authors & Country & Finding \\
\hline Jensen and Murphy (2010) & United States & Changes in executive compensation do not reflect changes in corporate performance. \\
\hline Walker (2010) & United States & Executive compensation has an inadequate relationship with long-term company performance. \\
\hline Sigler (2011) & United States & $\begin{array}{l}\text { Positive relationship between CEO compensation and company performance in terms of ROE, firm } \\
\text { size and CEO tenure. }\end{array}$ \\
\hline Abdullah and Wan (2013) & Malaysia & $\begin{array}{l}\text { Executive director remuneration is not linked to return on assets (ROA), but to the size and growth } \\
\text { of a company. }\end{array}$ \\
\hline Cybinski and Windsor (2013) & Australia & A clear link between company performance and CEO remuneration in large companies only. \\
\hline Kuo et al. (2013) & Taiwan & $\begin{array}{l}\text { Companies without employee reward systems performed generally worse than companies with } \\
\text { employee reward systems. }\end{array}$ \\
\hline Scholtz and Smit (2013) & South Africa & $\begin{array}{l}\text { A strong relationship was found between executive director remuneration and the performance } \\
\text { measures of turnover, total assets and share price. }\end{array}$ \\
\hline Callan and Thomas (2014) & United States & The pay-for-performance relationship is significant regardless the CEO compensation method. \\
\hline Bussin and Blair (2015) & South Africa & Profit drives CEO remuneration in most profit-generating companies. \\
\hline Bussin and Modau (2015) & South Africa & $\begin{array}{l}\text { A decreased relationship between CEO remuneration and performance (MVA, EVA, ROE and EPS) } \\
\text { after the } 2008 \text { financial crisis. }\end{array}$ \\
\hline Bussin and Nel (2015) & South Africa & $\begin{array}{l}\text { Very little to no relationship between financial performance (Du Pont model) and the guaranteed } \\
\text { cost-to-company of CEOs. }\end{array}$ \\
\hline
\end{tabular}

Note: Please see the full reference list of the article, Kirsten, E. \& Du Toit, E., 2018, 'The relationship between remuneration and financial performance for companies listed on the Johannesburg Stock Exchange', South African Journal of Economic and Management Sciences 21(1), a2004. https://doi.org/10.4102/sajems.v21i1.2004, for more information.

and executive director remuneration. The summary is categorised per year and shows the countries in which the studies were conducted.

The performance of both the company and executive directors are important, and both of these may be impacted by the remuneration packages chosen by the company. Although many studies have been performed over a period of 45 years, there is still no conclusive evidence as to the relationship between executive director remuneration and financial performance as many studies show conflicting results. This study attempted to confirm conclusions derived from previous studies conducted in South African and developing countries with more recent data. The following section addresses the research design and methods used in this empirical study.

\section{Research method}

The aim of the study was to investigate whether a relationship exists between performance remuneration of executive directors and the overall performance of a company. A quantitative research strategy was implemented to analyse the relationship between performance-based payments and the overall performance of companies.

\section{Setting, data collection and sampling strategy}

The focus area of the study was companies listed on the Johannesburg Stock Exchange (JSE), South Africa. To investigate the relationship between performance-based payments and the overall performance of companies, the consumer goods and services industry was used. This industry was chosen because of the companies' prominent sales figures, which can be used as a proxy for company size in relation to total executive director remuneration. In addition, using one industry eliminates the need to make provision for industryspecific differences between companies.

Company financial data was obtained from INET BFA, South Africa's leading provider of financial data feeds and analysis tools. Out of the 59 companies listed on the JSE from the consumer goods and services industry, 17 could not be used because of incomplete data. A sample of 42 listed South African companies from the consumer goods and services industry were used. The total population of South African consumer goods and services industry companies is relatively small, which makes it impossible to employ proper random sampling (see for example Vize et al. 2009). The sample companies' data for 2006 to 2015 were obtained and investigated. The result is 420 individual observations.

\section{Data and analysis method}

The independent variables used in the analysis were return on equity (ROE), return on assets (ROA), earnings per share (EPS), sales figure/turnover (TO) and price per share (PPS). ROE and ROA are presented as percentages, EPS and PPS as a rand value per share and $\mathrm{TO}$ as a total rand value. The dependent variable was the total executive director remuneration (REM) as a rand value, defined as executive directors' emoluments plus executive directors' share-based payments, both used in this study as disclosed on the Statement of Profit and Loss and Other Comprehensive Income. This figure for total director remuneration thus includes the executive directors' basic salary and bonus, as well as other forms of remuneration, such as share-based payments and options.

The statistical model set out to establish which of these independent variables show the most significant relationship to and perhaps represent a driving force behind director remuneration. The independent variables were chosen for the ease with which investors or other interested parties can obtain or calculate them, should these measures show a direct relationship with total director remuneration. The first control variable included in the model was the debt/ equity ratio (DE) as a proxy for size. Previous research has shown a direct positive relationship between leverage and firm size (Booth et al. 2001; Fama \& French 2002; Rajan \& 
Zingales 1995; Titman \& Wessels 1988). Even though the market capitalisation of companies is often included as a control variable for company size, market capitalisation correlates too closely with the price per share (PPS), which is considered to be an important variable not previously considered in the study by De Wet (2013). The second control variable was the JSE All Share Index (JSE), which is included to compensate for market-related changes over the period under consideration.

The variables were tested for stationarity, using the Augmented Dickey-Fuller (ADF) test. The results of the stationarity test indicated that the variables were nonstationary. Non-stationary data have a variance and a mean that changes over time, which will affect the results obtained from any statistical analyses that are performed on the data (Nason 2006). Non-stationary data can be converted by using a return that is calculated by the logarithm of a data point divided by the previous data point (Dahlhaus 1997). A drawback to the method of making data stationary is that one data point or sample member is lost in the process. If the sample had 45 points for instance, the regression analysis will run with only 44 points. The following equation is used to do the conversion from non-stationary to stationary data.

$$
R_{\text {Variable }}=\ln S_{\text {Variable }(t)}-\ln S_{\text {Variable }(t-1)}
$$

Calculating the natural logarithm and return for each variable has the benefit that variables, measured differently, become comparable, for example turnover as a total rand value and ROE as a percentage.

Descriptive statistics for the adjusted variables are presented in Table 2.

The skewness and excess kurtosis figures in Table 2 indicate that the data are not normally distributed. This is confirmed by significant Jarque-Bera test statistics for all series, despite the data being transformed by calculating the return of the natural logarithm of each variable. Departures from normality in financial time series are widely recognised in the literature and the results of the descriptive statistics are an indication of this (see Xiao and Aydemir 2007). Furthermore, all series are negatively skewed, except for changes in executive director remuneration, which is positively skewed.

A lack of normality calls for the use of a non-parametric test or bootstrapping. The use of non-parametric tests was deemed inappropriate for this study, therefore bootstrapping at a $95 \%$ confidence interval was applied. Bootstrapping also reduces the effect of a small sample size by adding robustness to the statistical tests (Field 2013). In addition, the data showed signs of heteroscedasticity, which also calls for the use of a regression model. The data show no significant sign of endogeneity, therefore the authors decided to ensure that the issue of heteroscedasticity is sufficiently addressed.

Table 3 presents the Pearson correlation results for the dataset making use of bootstrapping at a $95 \%$ confidence interval.

The results of the Pearson correlation (Table 3) indicated a clear correlation between total executive director remuneration (REM) and share price (PPS). Correlations with other financial performance measures were mainly negative and insignificant. A regression model would provide more insight into the relationship between executive director remuneration and share price.

An initial regression analysis on the data indicated by means of collinearity diagnostics, as well as the tolerance and variance inflation factor (VIF), that there is significant multicollinearity between ROA and ROE. For that reason, ROA was removed from the list of independent variables before commencing with the final regression model.

Conducting an analysis on time series data can include delayed effects because of the nature of financial data. The actions of executive directors do not necessarily have an immediate effect on the performance of the company and performance-based remuneration only occurs after said performance has been achieved. The Durbin-Watson test is used to observe the effect of autocorrelation in a dataset; for this study it was calculated at 0.946 . This is a clear indication of serial correlation between the errors in the regression model. According to Ghalayini and Noble (1996), the use of time series data can necessitate the use of a lagging metrics effect. This means that linear regression cannot be applied on the data as is and that a lag needs to be introduced for the

TABLE 2: Descriptive statistics.

\begin{tabular}{|c|c|c|c|c|c|c|c|}
\hline Variable & Mean & SD & Skewness & Kurtosis & JB stat & Max. & Min. \\
\hline REM & 0.013 & 0.053 & 0.720 & 12.518 & $1382.308 \dagger$ & 0.326 & -0.303 \\
\hline ROE & -0.165 & 2.718 & -18.528 & 348.259 & $1798605.000 \dagger$ & 3.059 & -51.160 \\
\hline ROA & -0.271 & 4.145 & -18.644 & 350.976 & $1826955.000 \dagger$ & 1.004 & -78.198 \\
\hline EPS & -0.017 & 0.308 & -5.304 & 60.070 & $50262.680 \dagger$ & 1.898 & -3.163 \\
\hline TO & 0.007 & 0.009 & -0.921 & 36.240 & $16532.090 \dagger$ & 0.082 & -0.083 \\
\hline PPS & 0.011 & 0.047 & -1.670 & 11.463 & $1234.904 \dagger$ & 0.152 & -0.305 \\
\hline $\mathrm{DE}$ & -0.382 & 5.938 & -2.950 & 82.383 & $94519.390 \dagger$ & 57.717 & -64.060 \\
\hline JSE & 0.005 & 0.055 & -16.723 & 303.283 & $1361717.000 \dagger$ & 0.025 & -1.000 \\
\hline
\end{tabular}

Note: The JB test is used as a test of normality (Jarque \& Bera 1987). The total number of observations for the full sample period is 378.

JB stat, Jarque-Bera test statistic; REM, remuneration; ROE, return on equity; ROA, return on assets; EPS, earnings per share; TO, turnover; PPS, price per share; DE, debt/equity ratio; JSE, Johannesburg Stock Exchange; SD, standard deviation; Max., Maximum; Min., Minimum.

$\dagger$, Statistical significance at the $1 \%$ level of significance. 


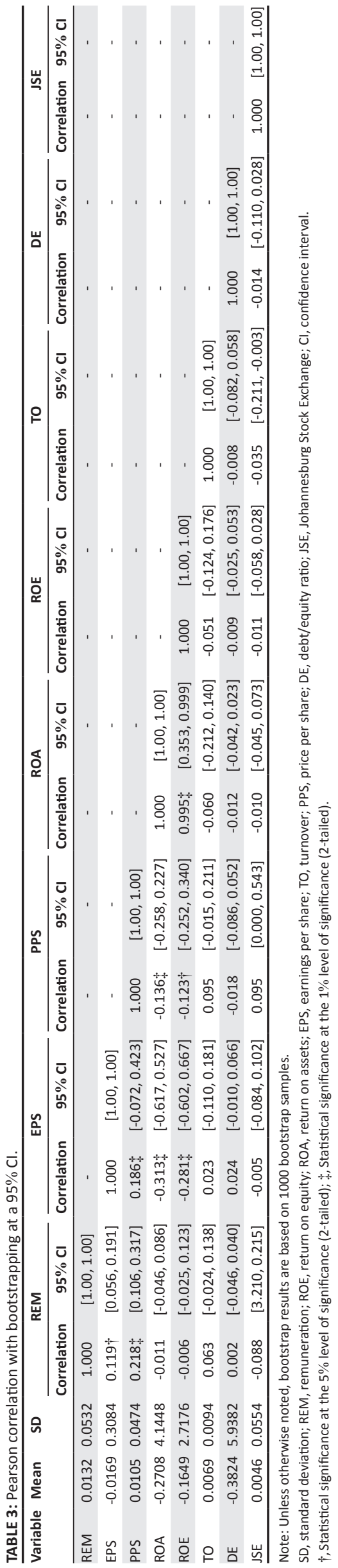

dependent variable. A lag of AR (1) was thus introduced to the dependent variable in the regression model to eliminate the effect of autocorrelation.

The variables for this study are all of a financial nature and therefore tend to be endogenous. Consequently, the use of only ordinary least squares regression could result in biased findings and erratic results as ordinary least squares regression ignores time-invariant unobserved individual effects and endogeneity (Flannery \& Hankins 2013; Maddala \& Lahiri 2009). Generalised least squares regression estimates unknown parameters in a linear regression model that can be applied when the variances of the observations are unequal or when there is a certain level of correlation between variables (Rana \& Al Amin 2015). The introduction of a lagged effect in the dependent variable significantly reduced the endogeneity of the dataset.

Linear regression was applied to the adjusted dataset, with bootstrapping at a $95 \%$ confidence interval (CI) to correct for non-normality and to compensate for the small sample size by adding robustness to the analysis.

The regression model can be expressed as follows:

$$
\begin{aligned}
R E M_{(t-1)} & =\beta_{0}+\beta_{E P S(t)}+\beta_{P P S(t)}+\beta_{R O E(t)} \\
& +\beta_{T O(t)}+\beta_{D E(t)}+\beta_{J S E(t)}+\varepsilon_{i t}
\end{aligned}
$$

The results of the regression analysis are presented in the next section.

\section{Results}

A summary of the results from the generalised least squares regression model, with bootstrapping at a $95 \% \mathrm{CI}$, is presented in Table 4.

The overall model is rather weak, but the results indicate that the variable with the biggest relationship to executive director remuneration is the share price of the company and the performance of the JSE All Share Index, both at $p<0.05$. In the South African environment, executive director remuneration is thus not directly related to profitability or company size, as was the case in most of the earlier studies. Further investigation into the reasons for the significant difference in results between this study and the one by De Wet (2013) showed that De Wet (2013) did not compensate for autocorrelation, which can be observed in the low Durbin-Watson statistic reported in his paper. Not taking autocorrelation into account can result in overestimated $\mathrm{t}$-statistics.

The lack of a relationship between executive director remuneration and company size, as well as between executive director remuneration and profitability, speaks to the results of studies by Bruce et al. (2005), Bussin and Nel (2015), Duffhues and Kabir (2008), Jensen and Murphy (2010), Meeks and Whittington (1975) and Walker (2010). 
TABLE 4: Regression results.

\begin{tabular}{lllll}
\hline Variable & $\boldsymbol{B}$ & $\mathbf{9 5 \%} \mathbf{C l}$ & $\boldsymbol{\beta}$ & $\boldsymbol{t}$ \\
\hline EPS & -0.006 & {$[-0.020,0.022]$} & -0.038 & -0.655 \\
PPS & -0.118 & {$[-0.251,-0.018]$} & -0.116 & -2.047 \\
ROE & -0.001 & {$[-0.001,0.005]$} & -0.038 & -0.663 \\
TO & 0.158 & {$[-0.327,0.776]$} & 0.031 & 0.041 \\
DE & 0.001 & {$[0.000,0.002]$} & 0.091 & 0.551 \\
JSE & -0.111 & {$[-0.344,0.196]$} & -0.127 & 0.582 \\
\hline
\end{tabular}

$\mathrm{Cl}$, confidence interval for B; EPS, earnings per share; PPS, price per share; ROE, return on equity; TO, turnover; DE, debt/equity ratio; JSE, Johannesburg Stock Exchange.

$R^{2}=0.044 ; N=322 ; p<0.001 ; t=3.481$.

However, the results are in line with the results of Bussin and Blair (2015), Conyon (1997), Conyon et al. (2000), Coughlan and Schmidt (1985), Fatemi et al. (2003), Gabaix and Landier (2008), Kato et al. (2007), Masson (1971), Murphy (1985) and Scholtz and Smit (2013). The link between executive director remuneration and share performance may be an indication that remuneration policies are based on the share price (or market capitalisation) and is thus directly connected to the principle of shareholder wealth maximisation. A reasonable explanation for this result can also be that executive directors in South Africa hold a significant number of shares in their own company (perhaps as part of a share-based option scheme) and is thereby incentivised with an increased share price.

\section{Discussion and conclusions}

The belief exists that management who are strongly motivated by money and personal gain are usually the ones tempted to act in a fraudulent manner. Brick et al. (2006) presented evidence that linked the underperformance of companies with excessive levels of executive director remuneration. Previous research indicated that search for a link between executive director remuneration and company performance lead to inconclusive and mixed results. To align the aims of executive directors with those of shareholders, performance will always remain a key requirement. This study aimed to investigate the existence and strength, if any, of the relationship between executive director compensation and company size and financial performance in South African companies from the consumer goods and services industry.

Based on the research it does not seem that there is a specific performance-based remuneration system preferred by companies. It appears that most companies implement a system which they deem works best for them. A generalisation may be made that most companies do not rely on only one form of remuneration, but they implement remuneration packages consisting of various types of remuneration methods. The more favourable forms of remuneration that packages are made up of seem to be normal salaries, cash bonuses and share options. The conclusion can thus be made that there is not one specific remuneration system and package that will work for all companies but that each company should implement a system which works best for them.

Bootstrapped Pearson correlation and bootstrapped generalised least squares regression were used to test whether there is a relationship between performance-based remuneration and the performance and size of companies. As most of the companies use different remuneration packages, the total executive director remuneration for each company was used as the dependent variable. The performance indicators were EPS, ROA, ROE, turnover, and share price.

From the initial correlation analysis, it seems that the variable which is most likely to have a relationship with total executive director remuneration and which will thus also be the best indicator for total executive director remuneration is share price. From the results, we conclude that executive director remuneration does not have a meaningful or significant relationship with any of the traditional performance measure variables of company performance. The lack of a relationship between executive director remuneration and accounting performance measures does not indicate that the companies did not take any performance measures into account when rewarding their executive directors; it simply indicates that financial performance was not the main driver for remuneration. Since executive director remuneration shows a significant relationship with share price, it can be that share performance - the true measure of shareholder wealth creation - is an indicator of executive director remuneration levels. Based on the results of this study, the conclusion can thus be made that South African companies within the consumer goods and services industry do not seem to base executive director remuneration on the accounting performance of the company but rather on its market performance.

The message these results send to potential investors is a comforting one. It means that executive directors are compensated for their ability to generate wealth for a company's shareholders.

There are several limitations under which this research study was executed, providing areas for future research. This study focused on the consumer goods and services industry as well as companies listed on the JSE. To attain more conclusive results, future research can be conducted on a wider range of industries as well as companies not listed or listed on other platforms.

The performance measures used to conduct the research were also limited to more traditional performance measures which can be calculated using traditional cost management systems and figures found on the financial statements. These traditional 
performance measures have various limitations which result in them being somewhat irrelevant in the current competitive markets (Ghalayini \& Noble 1996). A wide assortment of performance measures is available which include non-financial performance measures. Further research on the topic can be conducted using more modern performance measurement systems. Taking the more modern performance measures into account will provide a better insight into the current performance-based remuneration systems of companies. As recommended by Bussin and Blair (2015), it may also be worthwhile to investigate longer lag periods and investigate the relationship between executive director remuneration and financial performance over longer time periods.

A study can also be conducted on the exact content of each company's executive director remuneration, to establish how many shares each executive director holds in the company. Share-based remuneration options may create an incentive for executive directors to ensure that shareholder wealth is created.

\section{Acknowledgements}

The authors would like to thank two anonymous reviewers for their valuable comments to improve the quality of the article.

\section{Competing interests}

The authors declare that they have no financial or personal relationships that may have inappropriately influenced them in writing this article.

\section{Authors' contributions}

E.K. was the project leader, initiating the topic. She was mainly responsible for the literature review. E.d.T performed the statistical analyses and write-up of final results.

\section{References}

Abdullah, A.A. \& Wan, H.L., 2013, 'Relationships of non-monetary incentives, job satisfaction and employee job performance', International Review of Management and Business Research 2(4), 1085-1091.

Aguinis, H., Joo, H. \& Gottfredson, R.K., 2013, 'What monetary rewards can and cannot do: How to show employees the money', Business Horizons 56(2), 241. https://doi.org/10.1016/j.bushor.2012.11.007

Alshimmiri, T., 2004, 'Board composition, executive remuneration and corporate performance: The case of REITS', Corporate Ownership and Control 2(1), 104-118. https://doi.org/10.22495/cocv2i1p8

Anderson, R. \& Bizjak, J., 2003, 'Compensation committees: It matters who sets pay', Journal of Banking \& Finance 27, 1323-1348. https://doi.org/10.1016/S03784266(02)00259-5

Baumol, W.J., 1959, Business behavior, value and growth, Macmillan, New York.

Bebchuk, L.A. \& Fried, J.M., 2003, 'Executive compensation as an agency problem', The Journal of Economic Perspectives 17(3), 71-92. https://doi.org/10.1257/ 089533003769204362

Bebchuk, L.A. \& Spamann, H., 2010, 'Regulating bankers' pay', Georgetown Law Journal 98, 247-287.

Booth, L., Aivazian, V., Demirguc-Kunt, A. \& Maksimovic, V., 2001, 'Capital structures in developing countries', The Journal of Finance 56(1), 87-130. https://doi. org/10.1111/0022-1082.00320

Boshkoska, M., 2015, 'The agency problem: Measures for its overcoming', International Journal of Business and Management 10(1), 204-209.

Bourne, M., Mills, J., Wilcox, M., Neely, A. \& Platts, K., 2000, 'Designing, implementing and updating performance measurement systems', International Journal of Operations \& Production Management 20(7), 754-771. https://doi.org/ 10.1108/01443570010330739
Brick, I.E., Palmon, O. \& Wald, J.K., 2006, 'CEO compensation, director compensation, and firm performance: Evidence of cronyism?', Journal of Corporate Finance 12(3), 403-423. https://doi.org/10.1016/j.jcorpfin.2005.08.005

Bruce, A., Buck, T. \& Main, B.G., 2005, 'Top executive remuneration: A view from Europe*', Journal of Management Studies 42(7), 1493-1506. https://doi.org/ $10.1111 / \mathrm{j} .1467-6486.2005 .00553 . x$

Bryant, P. \& Davis, C., 2012, 'Regulated change effects on boards of directors: A look at agency theory and resource dependency theory', Academy of Strategic Management Journal 11(2), 1.

Buck, T., Bruce, A., Main, B.G. \& Udueni, H., 2003, 'Long term incentive plans, executive pay and UK company performance*', Journal of management Studies 40(7), 1709-1727. https://doi.org/10.1111/1467-6486.00397

Bussin, M., 2015, 'CEO pay-performance sensitivity in the South African context', South African Journal of Economic and Management Sciences 18(2), 232-244. https://doi.org/10.4102/sajems.v18i2.838

Bussin, M. \& Blair, C., 2015, 'Financial indicators of company performance in different industries that affect CEO remuneration in South Africa', South African Journal of Economic and Management Sciences 18(4), 534-550. https://doi.org/10.4102/ sajems.v18i4.1249

Bussin, M. \& Modau, M.F., 2015, 'The relationship between Chief Executive Officer remuneration and financial performance in South Africa between 2006 and 2012', SA Journal of Human Resource Management 13(1), 1-18. https://doi.org/10.4102/ sajhrm.v13i1.668

Bussin, M. \& Nel, M., 2015, 'Relationship between CEO remuneration and company financial performance in the South African retail and consumer goods sector', Acta Commercii 15(1), 1-11. https://doi.org/10.4102/ac.v15i1.240

Callan, S.J. \& Thomas, J.M., 2014, 'Relating CEO compensation to social performance and financial performance: Does the measure of compensation matter?', Corporate Social Responsibility and Environmental Management 21(4), 202-227. https://doi.org/10.1002/csr.1307

Cochran, P.L. \& Wood, R.A., 1984, 'Corporate social responsibility and financial performance', Academy of Management Journal 27(1), 42-56. https://doi. org $/ 10.2307 / 255956$

Colvin, G., 2008, 'American express gets CEO pay right', Fortune 21, 12-13.

Conyon, M.J., 1997, 'Corporate governance and executive compensation', International Journal of Industrial Organization 15(4), 493-509. https://doi. org/10.1016/S0167-7187(96)01032-6

Conyon, M.J., Peck, S.I. \& Sadler, G., 2000, 'Econometric modelling of UK executive compensation', Managerial Finance 26(9), 3-20. https://doi.org/10.1108/03074 350010766846

Cosh, A., 1975, 'The remuneration of chief executives in the United Kingdom', The Economic Journal 85(337), 75-94. https://doi.org/10.2307/2230529

Coughlan, A.T. \& Schmidt, R.M., 1985, 'Executive compensation, management turnover, and firm performance: An empirical investigation', Journal of Accounting and Economics 7(1-3), 43-66. https://doi.org/10.1016/0165-4101(85)90027-8

Cybinski, P. \& Windsor, C., 2013, 'Remuneration committee independence and CEO remuneration for firm financial performance', Accounting Research Journal 26(3), 197-221. https://doi.org/10.1108/ARJ-08-2012-0068

Dahlhaus, R., 1997, 'Fitting time series models to nonstationary processes', The Annals of Statistics 25(1), 1-37. https://doi.org/10.1214/aos/1034276620

De Wet, J., 2013, 'Executive compensation and the EVA and MVA performance of South African listed companies', Southern African Business Review 16(3), 57-80.

Duffhues, P. \& Kabir, R., 2008, 'Is the pay-performance relationship always positive?: Evidence from the Netherlands', Journal of Multinational Financial Management 18(1), 45-60. https://doi.org/10.1016/j.mulfin.2007.02.004

Dyl, E.A., 1988, 'Corporate control and management compensation: Evidence on the agency problem', Managerial and Decision Economics 9(1), 21-25. https://doi. org/10.1002/mde.4090090102

Edmans, A. \& Gabaix, X., 2009, 'Is CEO pay really inefficient? A survey of new optimal contracting theories', European Financial Management 15(3), 486-496. https:// doi.org/10.1111/j.1468-036X.2009.00500.x

Fahlenbrach, R. \& Stulz, R.M., 2011, 'Bank CEO incentives and the credit crisis', Journal of Financial Economics 99(1), 11-26. https://doi.org/10.1016/j.jfineco.2010. 08.010

Fama, E.F. \& French, K.R., 2002, 'Testing trade-off and pecking order predictions about dividends and debt', The Review of Financial Studies 15(1), 1-33. https://doi. org/10.1093/rfs/15.1.1

Fatemi, A., Desai, A.S. \& Katz, J.P., 2003, 'Wealth creation and managerial pay: MVA and EVA as determinants of executive compensation', Global Finance Journa 14(2), 159-179. https://doi.org/10.1016/S1044-0283(03)00010-3

Fernandes, N., 2008, 'EC: Board compensation and firm performance: The role of "independent" board members', Journal of Multinational Financial Management 18(1), 30-44. https://doi.org/10.1016/j.mulfin.2007.02.003

Field, A., 2013, Discovering statistics using IBM SPSS statistics, 4th edn., Sage, London.

Flannery, M.J. \& Hankins, K.W., 2013, 'Estimating dynamic panel models in corporate finance', Journal of Corporate Finance 19, 1-19. https://doi.org/10.1016/j. jcorpfin.2012.09.004

Frydman, C. \& Saks, R.E., 2010, 'Executive compensation: A new view from a longterm perspective, 1936-2005', Review of Financial Studies 96, 120-134. https:// doi.org/10.1093/rfs/hhp120

Gabaix, X. \& Landier, A., 2008, 'Why has CEO pay increased so much?', The Quarterly Journal of Economics 123(1), 49-100. https://doi.org/10.1162/qjec. 2008.123.1.49 
Ghalayini, A.M. \& Noble, J.S., 1996, 'The changing basis of performance measurment', International Journal of Operations \& Production Management 16(8), 63-80. https://doi.org/10.1108/01443579610125787

Gill, D., Prowse, V.L. \& Vlassopoulos, M., 2012, 'Cheating in the workplace: An experimental study of the impact of bonuses and productivity', Journal of Economic Behavior \& Organization 96, 120-134. https://doi.org/10.2139/ssrn. 2109698

Gomez-Mejia, L.R., Tosi, H. \& Hinkin, T., 1987, 'Managerial control, performance, and executive compensation', Academy of Management Journal 30(1), 51-70. https:// doi.org/10.2307/255895

Haynes, M., Thompson, S. \& Wright, M., 2007, 'Executive remuneration and corporate divestment: Motivating managers to make unpalatable decisions', Journal of Business Finance \& Accounting 34(5-6), 792-818. https://doi.org/10.1111/ j.1468-5957.2007.02008.x

Hirschey, M. \& Pappas, J.L., 1981, 'Regulatory and life cycle influences on manageria incentives', Southern Economic Journal 48(2), 327-334. https://doi.org/ 10.2307/1057933

Hovy, M., 2005, Future global remuneration strategies: Compliance, defiance or alignment?, Workspan: Redwood City, CA.

IoDSA, 2016, King IV report on corporate governance for South Africa Johannesburg, viewed 10 March 2018, from http://c.ymcdn.com/sites/www. iodsa.co.za/resource/resmgr/king_iv/King_IV_Report/IoDSA_King_IV Report_-_WebVe.pdf

Jarque, C.M. \& Bera, A.K., 1987, 'A test for normality of observations and regression residuals', International Statistical Review/Revue Internationale de Statistique 55(2), 163-172.

Jensen, M.C. \& Meckling, W.H., 1976, 'Theory of the firm: Managerial behavior, agency costs and ownership structure', Journal of Financial Economics 3(4), 305360. https://doi.org/10.1016/0304-405X(76)90026-X

Jensen, M.C. \& Murphy, K.J., 2010, 'CEO incentives - It's not how much you pay, but how', Journal of Applied Corporate Finance 22(1), 64-76. https://doi.org/10.1111/ j.1745-6622.2010.00262.x

Kato, T., Kim, W. \& Lee, J. H., 2007, 'Executive compensation, firm performance, and Chaebols in Korea: Evidence from new panel data', Pacific-Basin Finance Journa 15(1), 36-55. https://doi.org/10.1016/j.pacfin.2006.03.004

Kuo, T.-L., Ting, P.-J.L. \& Chiu, K.-H., 2013, 'Correlation between employee bonus and company performances: FTSE TWSE Taiwan 50 index companies', Journal of US company performances: FTSE TWSE Taiwan 50 in
China Public Administration 10(10), 993-1003.

Lewellen, W.G. \& Huntsman, B., 1970, 'Managerial pay and corporate performance', The American Economic Review 60, 710-720.

Lourenco, S.M.M., 2010, Do monetary incentives, feedback and recognition matter for performance? Evidence from a field experiment in a retail services company', DBA Harvard University, Cambridge, MA.

Maddala, G.S. \& Lahiri, K., 2009, Introduction to econometrics, Wiley: Hoboken, NJ.

Masson, R.T., 1971, 'Executive motivations, earnings, and consequent equity performance', The Journal of Political Economy 79, 1278-1292. https://doi.org/ 10.1086/259835

McGee, H.M., Dickinson, A.M., Huitema, B.E. \& Culig, K.M., 2006, 'The effects of individual and group monetary incentives on high performance', Performance Imdividual and group monetary incentives on high performance', Performance
Improvement Quarterly 19(4), 107-130. https://doi.org/10.1111/j.1937-8327. 2006.tb00387.x

Meeks, G. \& Whittington, G., 1975, 'Directors' pay, growth and profitability', The Journal of Industrial Economics 24(1), 1-14. https://doi.org/10.2307/2098094

Merrett, A. \& White, M., 1968, 'Incentive bonuses for executives', Managemen Decision 2(3), 159-161. https://doi.org/10.1108/eb000852

Mintzberg, H., 1978, 'Patterns in strategy formulation', Management Science 24(9), 934-948. https://doi.org/10.1287/mnsc.24.9.934

Mueller, D.C., 2006, 'Corporate governance and economic performance', International Review of Applied Economics 20(5), 623-643. https://doi.org/10.1080/ 02692170601005598

Murphy, K.J., 1985, 'Corporate performance and managerial remuneration: An empirical analysis', Journal of Accounting and Economics 7(1), 11-42. https:// doi.org/10.1016/0165-4101(85)90026-6

Nason, G.P., 2006, 'Stationary and non-stationary time series', Statistics in Volcanology. Special Publications of IAVCEI 1, 129-142.
Neely, A., Gregory, M. \& Platts, K., 2005, 'Performance measurement system design: A literature review and research agenda', International Journal of Operations \& Production Management 25(12), 1228-1263.

O'Neill, G.L. \& lob, M., 1999, 'Determinants of executive remuneration in Australian organizations: An exploratory study', Asia Pacific Journal of Human Resources 37(1), 65-75. https://doi.org/10.1177/103841119903700106

Ozkan, N., 2007, 'Do corporate governance mechanisms influence CEO compensation? An empirical investigation of UK companies', Journal of Multinational Financial Management 17(5), 349-364. https://doi.org/10.1016/j.mulfin.2006.08.002

Pascual-Ezama, D., Prelec, D. \& Dunfield, D., 2013, 'Motivation, money, prestige and cheats', Journal of Economic Behavior \& Organization 93, 367. https://doi.org/ 10.1016/j.jebo.2013.03.015

Pass, C., 2003, 'Long-term incentive schemes, executive remuneration and corporate performance: An empirical study', Corporate Governance: The International Journal of Business in Society 3(4), 18-27. https://doi.org/10.1108/14720700310497087

Rajan, R.G., 2005, Has financial development made the world riskier?, viewed 10 March 2018, from http://www.nber.org/papers/w11728

Rajan, R.G. \& Zingales, L., 1995, 'What do we know about capital structure? Some evidence from international data', The Journal of Finance 50(5), 1421-1460. https://doi.org/10.1111/j.1540-6261.1995.tb05184.x

Rana, S. \& Al Amin, M., 2015, 'An alternative method of estimation of SUR model', American Journal of Theoretical and Applied Statistics 4(3), 5. https://doi. org/10.11648/j.ajtas.20150403.20

Samnani, A.-K. \& Singh, P., 2014, 'Performance-enhancing compensation practices and employee productivity: The role of workplace bullying', Human Resource Management Review 24(1), 5. https://doi.org/10.1016/j.hrmr.2013.08.013

Scholtz, H. \& Smit, A., 2013, 'Executive remuneration and company performance for South African companies listed on the Alternative Exchange (AltX)', Southern African Business Review 16(1), 22-38.

Schulz, E.R., 1997, 'The influence of group incentives, training and other human resource practices on firm performance and productivity', PhD, Rutgers The State University of New Jersey New Brunswick.

Shin, T., 2013, 'Fair pay or power play? Pay equity, managerial power, and compensation adjustments for CEOs', Journal of Management 42(2), 419-448.

Sigler, K.J., 2011, 'CEO compensation and company performance', Business and Economic Journal 2011, 1-8.

Spicer, B.H., 1978, 'Investors, corporate social performance and information disclosure: An empirical study', Accounting Review 53, 94-111.

Sun, S.L., Zhao, X. \& Yang, H., 2010, 'Executive compensation in Asia: A critical review and outlook', Asia Pacific Journal of Management 27(4), 775-802. https://doi. org/10.1007/s10490-010-9207-7

Titman, S. \& Wessels, R., 1988, 'The determinants of capital structure choice', The Journal of Finance 43(1), 1-19. https://doi.org/10.1111/j.1540-6261.1988.tb02585.x

Tosi, H.L. \& Gomez-Mejia, L.R., 1994, 'CEO compensation monitoring and firm performance', Academy of Management Journal 37(4), 1002-1016. https://doi. org/10.2307/256609

Van Zyl Smit, J. \& Nel, S., 2010, 'Executive compensation', Accountancy SA 11(2), https://www.accountancysa.org.za/executive-compensation/

Vize, R., Coughlan, J., Kennedy, A. \& Ellis-Chadwick, F., 2009, 'Investigating the factors impacting retailers evaluations of web solution providers', Dublin Institute of Technology, Dublin.

Walker, D.I., 2010, 'The challenge of improving the long-term focus of executive pay', $B C L$ Review 51, 435.

Wilkinson, M., 2009, 'Sharing the gains', Charter 80(3), 38-41.

Xiao, L. \& Aydemir, A., 2007, 'Volatility modelling and forecasting in finance', Forecasting Volatility in the Financial Markets 3, 1-45. https://doi.org/10.1016/ B978-075066942-9.50003-0

Xiaoning, B., 2009, 'The wages of sin', China Daily, 11-17 May.

Yanadori, Y. \& Milkovich, G.T., 2002, Origin of CEO and compensation strategy: Differences between insiders and outsiders, CAHRS Working Paper Series, 44, Cornell University: Ithaca, NY.

Zhu, J., 2007, 'The empirical study on the effect factor of top management remuneration in China', Journal of American Academy of Business 11(2), 213-221. 